\title{
Use of PCR-DGGE Based Molecular Methods to Analyse Microbial Community Diversity and Stability during the Thermophilic Stages of an ATAD Wastewater Sludge Treatment Process as an Aid to Performance Monitoring
}

\author{
Anna V. Piterina and J. Tony Pembroke \\ Department of Chemical and Environmental Sciences and the Material and Surface Science Institute (MSSI), \\ University of Limerick, Limerick, Ireland \\ Correspondence should be addressed to J. Tony Pembroke; tony.pembroke@ul.ie
}

Received 26 July 2013; Accepted 20 August 2013

Academic Editors: B. Castiglioni and A. D’Annibale

Copyright (C) 2013 A. V. Piterina and J. T. Pembroke. This is an open access article distributed under the Creative Commons Attribution License, which permits unrestricted use, distribution, and reproduction in any medium, provided the original work is properly cited.

\begin{abstract}
PCR and PCR-DGGE techniques have been evaluated to monitor biodiversity indexes within an ATAD (autothermal thermophilic aerobic digestion) system treating domestic sludge for land spread, by examining microbial dynamics in response to elevated temperatures during treatment. The ATAD process utilises a thermophilic population to generate heat and operates at elevated $\mathrm{pH}$ due to degradation of sludge solids, thus allowing pasteurisation and stabilisation of the sludge. Genera-specific PCR revealed that Archaea, Eukarya and Fungi decline when the temperature reaches $59^{\circ} \mathrm{C}$, while the bacterial lineage constitutes the dominant group at this stage. The bacterial community at the thermophilic stage, its similarity index to the feed material, and the species richness present were evaluated by PCR-DGGE. Parameters such as choice of molecular target (16S rDNA or rpoB genes), and electrophoresis condition, were optimised to maximise the resolution of the method for ATAD. Dynamic analysis of microbial communities was best observed utilising PCR-DGGE analysis of the V6-V8 region of 16S rDNA, while rpoB gene profiles were less informative. Unique thermophilic communities were shown to quickly adapt to process changes, and shown to be quite stable during the process. Such techniques may be used as a monitoring technique for process health and efficiency.
\end{abstract}

\section{Introduction}

Autothermal thermophilic aerobic digestion (ATAD), an advanced tertiary sludge treatment process, is used to produce a stabilized sludge (Class A biosolids) suitable for land spread [1-4]. ATAD treatment involves aeration in insulated jacketed reactors operating in a semibatch mode with temperatures ranging from $10^{\circ} \mathrm{C}$ at inlet to an average $65^{\circ} \mathrm{C}$ during the thermophilic stage. Microbial activity in the reactors, stimulated by aeration, results in the digestion of sludge solids, generating heat which is trapped in the insulated reactors, resulting in a rise in temperature (on occasion up to $70^{\circ} \mathrm{C}$ ) and a $\mathrm{pH}$ rise to $\mathrm{pH} 9$ as a result of ammonia generation from proteolysis. The combined activities of microbial degradation, alkalinity, and heat generation stabilize the sludge solids, while the heat results in pasteurization. Multiple factors, such as aeration, feed composition, feeding cycles, and operational parameters, determine the maximum temperature and time course achievable within the thermophilic stage $[3,5]$. The sustainability of such a process is dependent on the long-term stability of the ecosystem and the activity of the microbial consortia within it, which in turn is highly dependent on ATAD design and operation [6]. When operating well, ATAD had been shown to remove enteric pathogens efficiently which is a prerequisite for its use as a fertilizer for land spread [7]. Therefore, measurement of the community structure, the diversity of species within the ecosystem, and the community dynamics as a function, of process stage and temperature are of critical importance as indicators not only of the health and stability of an ATAD process but for any wastewater treatment process $[8,9]$. Diversity indices, which characterize an existing ecosystem, are known to be affected 
by perturbation in operational parameters and exposure to toxic or inhibitory substances or prevailing conditions, and they often correlate with nutrient limitations within the system. The rate of transition to extreme conditions can be important in allowing time for adaptation and succession to develop, while transition to extreme conditions can also result in lysis, denaturation of extracellular enzymes, inactivation of mesophilic microorganisms, the arrest of certain biodegradation process, and the initiation of others favored by the new conditions within the ATAD ecosystem. Thus, development and validation of biochemical and molecular methodologies to monitor and improve our understanding of the behavior of microbial communities within the ATAD system are required. Advances in molecular tools can allow unprecedented opportunities for detailed studies of species population structure and dynamics within biotechnological processes [10-12]. Determination of microbial abundance has often been a key focus accomplished by direct DNA extraction followed by PCR amplification of genera or domain-specific genetic biomarkers [13-16] and recovery of $16 \mathrm{~S}$ rDNA sequences of Bacteria and Achaea and $18 \mathrm{~S}$ rDNA of active fungi and eukaryotic organisms [17], while internal transcribed spacer (ITS) sequences within ribosomal operons are also informative [18]. Molecular fingerprints of diversity can be achieved by coupling PCR amplification of taxonomical targets with sequence dissimilarities analyzed by denaturing gradient gel electrophoresis (DGGE) enabling the separation of DNA fragments of identical length but of different sequence $[19,20]$, resulting in a DGGE fingerprint that is specific for the sample site. Although no standard tool exists, a variety of comparison tools are available to compare fingerprints [21] and include visual inspection, cluster analysis, nonmetric multidimensional scaling and moving window analysis, which allow several quantitative and qualitative biodiversity indices to be recovered. The Shannon diversity index $\left(H^{\prime}\right)$ is a quantitative index which computes band intensity with species abundance [22], while the estimation of species richness $(S)$ provides qualitative data relating the total number of bands observed to the total species number and species richness $(S)$ and corresponds to the total number of unique biomarker sequences within the ecosystem. PCRDGGE is capable of detecting as much as $95-99 \%$ of the bacterial community, and several candidate sequences can be used as genetic biomarkers including variable regions within the $16 \mathrm{~S}$ ribosomal DNA gene [23], the $23 \mathrm{~S}$ ribosomal DNA gene, and the $r p o B$ gene (encoding the $\beta$ subunit of RNA polymerase) [24], which are universally present with highly conserved flanking regions allowing the simultaneous amplification with "universal primers" $[25,26]$. Due to the length and sequence of polymorphisms, the choice of primers, their specificity and degree of mismatch, the reproducibility of extracting DNA from environmental samples with complex and diverse microbial communities and natural materials will affect the recovery of biodiversity indices [27-32]. PCR bias resulting from inhibition by coextracted impurities or preferential amplification of certain species by various primer pairs is also a key issue [31, 33-35]. Other important issues include the degree of genetic polymorphism within the target regions within the community [36], comigration of PCR fragments from different species in the same DGGE band [37], and the formation of multiple bands during amplification of genes from a single genome [38, 39]. Application of DGGE methodology also has size limitations of 100-500 bp, which may affect the probe design and further phylogenetic analyses, while subsequent quantitative analysis of the DGGE fingerprint obtained assumes that the number of bands reflects the microbial diversity in the sample $[20,21,34]$ and that their relative intensity reflects abundance. The genomic copy number of $16 \mathrm{~S}$ rDNA in certain species [40, 41], which can vary from one to more than 10 copies per cell [42], can also have a major effect $[43,44]$, while the occurrence of heteroduplex molecules [25] can effect interpretation. Hence, alternative biomarkers for PCR-DGGE fingerprints, such as the single copy $r p o B$ gene [24], have been investigated, but because of amplification failure in certain strains [24] and limited information on primer specificity for $r p o B$, widespread application of this biomarker has been limited at least until more data on $r p o B$ sequences is available. Thus, when utilizing PCR-DGGE to assess indicators of biodiversity and health of the ATAD process, understanding the key factors associated with the recovery of biodiversity is essential for optimizing the methodology.

\section{Material and Methods}

2.1. Sampling Site. Sampling was carried out at the municipal ATAD plant in Killarney, Co. Kerry, Ireland. Details of the plant, operating parameters, physicochemical characteristics for different stages of the ATAD process, pattern of organic matter transformation, and overall performance of the plant have been described $[2,30,45,46]$. The daily feed rate was in the range of $15-30 \mathrm{~m}^{3} \cdot \mathrm{d}^{-1}$ with the thickened sludge undergoing thermophilic digestion in a two-reactor (1A and $2 \mathrm{~A}$ of $110 \mathrm{~m}^{3}$ ) semibatch process before the treated sludge was stored. Reactor 1A (the mesophilic reactor) operated between 35 and $49^{\circ} \mathrm{C}$ while Reactor $2 \mathrm{~A}$ (the thermophilic reactor), operated between 58 and $65^{\circ} \mathrm{C}$.

2.2. Analytical Methods. Samples were taken at feed inlet (raw sludge untreated), from Reactor $1 \mathrm{~A}$, Reactor $2 \mathrm{~A}$, and from sludge storage (following treatment), in triplicate from the middle of each reactor via a sterile deep-water sampling device.

2.3. DNA Extraction. To enhance DNA extraction recovery and maximize diversity recovery, two extraction methods were applied in this study. A "Power Soil" DNA isolation kit (MOBIO, UK) was used as recommended by the manufacturer and another extraction protocol as described [31].

2.4. PCR Amplification. Oligonucleotides utilized in this study are detailed in Table 1 . PCR primers amplifying different variable regions of the 16S rDNA (V3-V5 and V6V8) and $r p o B$ genes were used as described previously, except that PCR reaction contained 1\% formamide (Sigma, $\mathrm{UK}$ ) and $25 \mathrm{ng}$ of nonacetylated BSA (Roche, UK) to limit inhibition of PCR reaction by impurities, originated from the thermophilic sludge [31]. To minimize PCR artefacts, 
TABLE 1: List of the oligonucleotide primers utilized in this study.

\begin{tabular}{|c|c|c|c|c|c|}
\hline \multicolumn{2}{|c|}{ Primer } & \multirow[b]{2}{*}{ Sequence $\left(5^{\prime}-3^{\prime}\right)^{2}$} & \multirow[b]{2}{*}{ Specificity } & \multirow[b]{2}{*}{ Techniques } & \multirow[b]{2}{*}{ Reference } \\
\hline $\begin{array}{l}\text { Taxonomic } \\
\text { lineage }\end{array}$ & Name of primer & & & & \\
\hline \multirow{8}{*}{ Bacteria } & $27 \mathrm{~F}^{1}$ & AGAGTTTGATCCTGGCTCAG & V1, 16S rDNA & PCR & [63] \\
\hline & $1492 \mathrm{R}^{1}$ & GGTTACCTTGTTACGACTT & V9, 16S rDNA & PCR & {$[63]$} \\
\hline & GC-338F & ACTCCTACGGGAGG CAGCAG & $16 \mathrm{~S}$ rDNA & PCR, DGGE & [19] \\
\hline & $518 \mathrm{R}$ & ATTACCGCGGCTGCTGG & $16 \mathrm{~S}$ rDNA & PCR, DGGE & {$[19]$} \\
\hline & GC-948F & AACGCGGAAGAACCTTAC & V6, $16 \mathrm{~S}$ rDNA & PCR, DGGE & [39] \\
\hline & L1401R & CGGTGTGTACAAGAAGACCC & V8, $16 \mathrm{~S}$ rDNA & PCR,DGGE & {$[63]$} \\
\hline & GC-rpoB1698F3 & AACATCGGTTTGATCAAC & rрoB & PCR, DGGE & {$[24]$} \\
\hline & rpoB2041R & CGTTGCATGTTGGTACCCAT & rpoB & PCR, DGGE & [24] \\
\hline \multirow{2}{*}{ Fungi } & F3F & TCCTCTAAATGACCAAGTTTG & $18 \mathrm{~S}$ rRNA & PCR & {$[13]$} \\
\hline & EF4R & GGAAGGG[G/A]TGTATTTATTAG & $18 \mathrm{~S}$ rRNA & PCR & {$[13]$} \\
\hline \multirow{2}{*}{ Archaea } & Arc $21 \mathrm{~F}$ & TTCCGGTTGATCCYGCCGGA & $16 \mathrm{~S}$ rRNA & PCR & {$[64]$} \\
\hline & Arc 958R & YCCGGCGTTGAMTCCAATT & $16 \mathrm{~S}$ rRNA & PCR & [64] \\
\hline \multirow{2}{*}{ Eukarya } & Euk1427F & TCTGTGATGCCCTTAGATGTTCTGGG & $18 \mathrm{~S}$ rRNA & PCR & {$[65]$} \\
\hline & Euk1616R & GCGGTGTGTACAAAGGGCAGGG & $18 \mathrm{~S}$ rRNA & PCR & {$[65]$} \\
\hline
\end{tabular}

${ }^{1} \mathrm{~F}$ : forward primer; R: reverse primer. The numbering denotes positions of primers relative to the E. coli 16S rDNA gene.

${ }^{2}$ GC clamp added to the $5^{\prime}$ end of the primer 338, 5'CGCCCGCCGCGCGCGGCGGGCGGGGCGGGGGCACGGGGG G $3{ }^{\prime}$.

Sequences represent the nucleotide sequences in the GC clamps of the respective primers.

the PCR amplification procedure was optimized using increased primer concentration to enhance the ratio of primer to template (30 pmol) [47], thus favoring primer annealing, and the amplification cycles were reduced from 30 to 20 . Multiple $(N=10)$ PCR reaction mixtures for each DNA sample and for each PCR primer set were combined [40] and concentrated with two volumes of ethanol and glycogen [48]. Pellets were dissolved in $10 \mathrm{mM}$ Tris- $\mathrm{HCl}$ ( $\mathrm{pH} 8.0$ ) to a final concentration $100 \mathrm{ng} \cdot \mu \mathrm{l}^{-1}$.

2.5. Denaturing Gradient Gel Electrophoresis (DGGE) Analysis. The PCR products were analyzed by denaturing gradient gel electrophoresis (DGGE) using the C.B.S. Scientific Co., Inc. (Del Mar, USA) system with integrated buffer and heating. Gel size was $22 \times 22 \mathrm{~cm}$ and $0.75 \mathrm{~mm}$ thick with the electrophoresis buffer $(0.5 \mathrm{X} \mathrm{TAE})$ maintained at $60^{\circ} \mathrm{C}$ during electrophoresis.

2.6. Preparation of a Reference Marker. To allow comparative analysis of DGGE patterns, a marker containing products amplified with primers from known bacterial species was used in each analysis. For this purpose, six bacterial strains, Bacillus thuringiensis NCIMB 9134 T, Bacillus cereus ATCC 14579, Escherichia coli JM 109, Salmonella enterica ATCC 29629, and two bacterial strains isolated and identified from ATAD sludge Bacillus subtilis ATAD 1 and Bacillus licheniformis ATAD 6, were routinely used. A colony of each isolate was suspended in $50 \mu \mathrm{L}$ lysis buffer $(0.05 \%$ SDS; $0.03 \mathrm{M}$ $\mathrm{NaOH}$ ) and incubated for $15 \mathrm{~min}$ at $95^{\circ} \mathrm{C} .450 \mu \mathrm{L}$ of distilled water was added and centrifuged for $5 \mathrm{~min}$ at 13,000x rpm, and $1 \mu \mathrm{L}$ of each supernatant was used for PCR. The migration behavior of each of the amplicons was analyzed via DGGE, and those showing different migration distances on the gel were combined and used as a reference lane. Marker samples were stored at $-80^{\circ} \mathrm{C}$.

\subsection{Optimizing the DGGE Protocol for ATAD Samples}

(a) Sample Electrophoresis Time. Optimal duration of electrophoresis and migration via time course experiments was evaluated to obtain maximum resolution for samples from ATAD Reactors $1 \mathrm{~A}$ and $2 \mathrm{~A}$ and product following processing. $500 \mathrm{ng}$ of PCR amplicon was subjected to electrophoresis for $1,2,3,10,16,18$, and $19 \mathrm{~h}$ at $75 \mathrm{~V}$ and $250 \mathrm{~V}$, with buffer temperature maintained at $60^{\circ} \mathrm{C}$ on $8 \%$ or $10 \%$ PAAG for $r p o B$ fragment amplicons, 1, 2, 3, 10, 16, 18, and $19 \mathrm{~h}$ at $75 \mathrm{~V}$ and $250 \mathrm{~V}$ on $6 \%$ or $8 \%$ PAAG for V6-V8 amplicons, and $8 \%$ or $10 \%$ for V3-V5 amplicons of $16 \mathrm{~S}$ rDNA.

(b) Optimization of Sample Loading to Maximize DGGE Band Recovery. The detection limit of bands achievable by DGGE analysis is variable, but optimization is essential to maximize biodiversity index recovery from a DGGE fingerprint. The amount loaded can depend on the total number of different amplicons, their copy number, and the species diversity and richness present, factors that are often impossible to predict prior to analysis. Thus, the amount of PCR product loaded on gels was varied within the range of $100 \mathrm{ng}$ to $5 \mu \mathrm{g}$. Gels giving the maximum banding patterns were chosen for comparative DGGE analysis. At least two gels using the same conditions were routinely used for such comparative analysis. Gels were stained with either silver stain [49] or ethidium bromide [48].

(c) Analysis and Comparison of DGGE Patterns. DGGE profiles were analyzed for similarities via digital image analysis using the BioNumerics 4.0 software package. DGGE bands 
TABLE 2: Detection of microbial diversity in ATAD sludge at different stages of ATAD treatment. PCR amplification using Archaea-, Eukarya-, Bacteria-, and Fungal-specific primers as listed in Table 1 was used.

\begin{tabular}{|c|c|c|c|c|}
\hline \multirow{2}{*}{ Origin of the extracted DNA } & \multicolumn{4}{|c|}{ PCR amplification with genera- and domain-specific primers } \\
\hline & Eukarya & Archaea & Bacteria & Fungi \\
\hline Inlet type I (sewage) & + & + & + & + \\
\hline Inlet type II (secondary sludge) & + & - & + & + \\
\hline Thickened inlet sludge & + & + & + & + \\
\hline Reactor 1A ATAD (2 hours of operation) & + & - & + & + \\
\hline Reactor 1A ATAD (4 hours of operation) & - & - & + & + \\
\hline Reactor 1A ATAD (16 hours of operation) & - & - & + & - \\
\hline Rector 2A ATAD (4 hours of operation) & - & - & + & - \\
\hline Reactor 2A ATAD (23 hours of operation) & - & - & + & - \\
\hline Biosolids (9 days and storage) & + & - & + & + \\
\hline
\end{tabular}

Positive detection is indicated as (+) ve whereas lack of amplification is indicated as (-) ve.

were detected using the band-search algorithm and following background subtraction; profiles were normalized using a species standard as a reference. Only those bands with a peak height intensity exceeding $1.0 \%$ of the strongest band in each lane were included for further analyses. A mathematical diversity index (complexity richness $(S)$ ) was calculated for each PCR-DGGE fingerprint generated from sludge samples taken at different stages of ATAD treatment by the softwarebased enumeration of the total number of bands in each lane as well the number of unique bands in the DGGE profile obtained for thermophilic sludge DNA. The \% similarity between the two fingerprints was calculated based on the number of common bands between two fingerprints. The $\%$ change value matrix was used to perform moving window analysis by plotting the values between two consecutive sampling points:

$$
\% \text { changes }=100-\% \text { similarity }
$$

(see [21]). Consecutively, the rate of change $\left(D_{t}\right)$ of overall community dynamic was calculated according to the average of the respective moving window curve data points:

$$
D_{t}=\sum_{N}(\% \text { changes })=\Delta t
$$

(see [21]). The bigger the change between DGGE profiles from two consecutive sampling points, is the higher the corresponding moving window curve data point will be and, hence, the higher the $D_{t}$ values. A range-weighted richness $(\mathrm{Rr})$ index can be mathematically expressed by defining the total number of bands observed multiplied by the percentage of denaturing gradient needed to generate the total diversity of the sample. This value describes a carrying capacity of an environment containing wide species GC variability (both in terms of percentage and in terms of positioning of the GC stretches within the $16 \mathrm{~S}$ rDNA gene). This value was characterized according to the following formula:

$$
\mathrm{Rr}=N^{2} \times D_{g}
$$

(see [21]), where $N$ represents the total number of bands in the pattern and $D_{g}$ the denaturing gradient occurring between the first and the last band of the pattern analyzed. $\mathrm{Rr}$ (richness) was determined from fingerprints for each type of sludge sampled during the ATAD process and for each experimental setting. Similarities between DGGE patterns were calculated using band presence or absence via pairwise similarity of the banding patterns for the different samples, and clustering of patterns was calculated using the unweighted pair group method using average linkages (UPGMA) to determine whether the samples revealed a nonrandom pattern and whether they clustered according to specific patterns (temperature in the reactors, time of operation within the same reactor, or aeration effects). It was hypothesized that important environmental stressors may be determined by the application of such methods.

\section{Results}

3.1. PCR Survey of the Biodiversity of the ATAD Ecosystem. High-molecular-weight total genomic DNA extracts were prepared from sludge samples taken during the ATAD process by a combination of two direct DNA extraction methodologies to maximize DNA template recovery as recommended previously $[31,32]$. A PCR survey of the recovered DNA templates using a variety of genera-specific primers (Table 2) was performed. Results revealed that the ATAD system is dynamic and undergoes decline in the number of lineages as the treatment proceeds, possibly due to increased $\mathrm{pH}$ and temperature within the ATAD process. Archaeal lineages (Table 3), although detected in the feed, were below detection limits at later stages of the ATAD process. Fungi were also detected in the feed sludge and within the mesophilic sludge (Reactor 1A) and were detected again within the stored product but were not detected in the thermophilic reactor 2A. Eukaryotic sequences were also not detected in the thermophilic ATAD reactor. Genomic DNA from bacterial lineages was detected at all stages of the ATAD treatment, with only bacterial species being detected at the thermophilic stage (Reactor 2A). 
TABLE 3: Optimized conditions for DGGE analysis.

Optimal parameters (DGGE analysis)

\begin{tabular}{|c|c|c|c|c|c|c|c|}
\hline Amplicon & Primers set & $\begin{array}{l}\text { Amount of } \\
\text { DNA } \\
\text { template in } \\
\text { PCR reaction }\end{array}$ & Voltage, $\mathrm{V}$ & Time, hrs & $\begin{array}{c}\text { Denaturant } \\
\text { range, }(\%)\end{array}$ & $\begin{array}{c}\text { Amount of } \\
\text { amplicon } \\
\text { (per lane), } \mu \mathrm{g}\end{array}$ & $\begin{array}{l}\text { Gel staining } \\
\text { methods }\end{array}$ \\
\hline V3-V5; 16S rRNA & $338 \mathrm{~F}-\mathrm{GC}^{*} / 518 \mathrm{R}$ & $300 \mathrm{ng}$ & 75 & 16 & $35-75$ & 4.5 & $\mathrm{EtBr}$ \\
\hline V6-V8, 16S rRNA & 948F-GC*/L1401 & $300 \mathrm{ng}$ & 75 & 18 & $40-65$ & $\begin{array}{c}1.5 \\
3\end{array}$ & $\begin{array}{l}\text { Silver stain } \\
\text { EtBr }\end{array}$ \\
\hline rpoB & $1698 \mathrm{~F}-\mathrm{GC}^{*} / 2043 \mathrm{R}$ & $600 \mathrm{ng}$ & 75 & 16 & $30-60$ & 0.3 & $\begin{array}{c}\text { EtBr, silver } \\
\text { stain }\end{array}$ \\
\hline
\end{tabular}

*GC clamp added to the $5^{\prime}$ end of the primers 338F, 948F, and 1698F, 5'CGCCCGCCGCGCGCGGCG GGCGGGGCGGGGGCACGGGGGG-3'.

\subsection{DGGE Fingerprinting of Bacterial Community Diversity.} Based on the initial PCR survey, the major driving force for the elevated temperature and the biodegradation occurring at elevated temperature within the ATAD process would appear to be bacteria. To determine the nature of the bacterial populations supported at each stage of ATAD, we utilized PCR-DGGE profiling techniques. PCR fragments for wellknown taxonomical biomarkers such as V3-V5 and V6-V8 regions of the $16 \mathrm{~S}$ rDNA and the $r p o B$ gene were amplified from the DNA template, recovered from ATAD, and analyzed following optimization of template extraction, template amplification, and DGGE separation. By optimization of the DGGE protocol, it was possible to maximize band recovery for all types of DNA profiles (of mesophilic and thermophilic origin) analyzed which resulted in excellent band separation, detection, and visualization (Table 4). Comparison of the DGGE band patterns sampled from the same ATAD stage showed a high degree of reproducibility both between PCR amplifications, where the same DNA extract was amplified multiple times, and between DGGE gels, where the same PCR product was loaded several times.

Optimized conditions were utilized to profile heterogeneity within the total pool of amplified V3-V5 and V6V8 amplicons of the 16S rDNA and the $r p o B$ gene from templates derived from various ATAD samples, and then, these DGGE fingerprints and band patterns were compared and evaluated. The patterns recovered indicated that the ATAD process is a dynamic ecosystem (Figure 1). Shifts in bacterial composition at different times during the ATAD treatment were observed for patterns produced by the three taxonomic genetic markers used. Many bands present at the autoheating stage (Reactor 1A) were absent from the DGGE pattern at a later stage in the ATAD process (Reactor $2 \mathrm{~A}$ ) indicative of succession and adaptation of new species to the new process conditions and the replacement of species that perhaps cannot adapt. In the DGGE community fingerprint of 3 biomarkers obtained from Reactor 2A, a new DGGE band pattern could be observed indicating the development or growth of new bacterial species under these operational parameters. The new bands observed in the Reactor 2A DGGE fingerprint (Figure 1) for all 3 biomarkers migrate further in the gel indicating a highermelting temperature for these DNA amplicons than for those recovered from
TABLE 4: Comparison of range-weighted richness (Rr) for bacterial diversity at different stages of ATAD treatment obtained by various primer sets in this study and values reported in other studies from different industrial and native ecosystems. $\mathrm{Rr}$ was calculated for each DGGE profile obtained as described in Section 2. The highest $\mathrm{Rr}$ values are shown in bold.

\begin{tabular}{|c|c|c|c|c|}
\hline \multirow{3}{*}{ Fingerprint type } & \multicolumn{4}{|c|}{ Range-weighted richness, $\mathrm{Rr}$} \\
\hline & \multicolumn{2}{|c|}{$16 \mathrm{~S}$ rDNA } & \multirow{2}{*}{ rpoB } & \multirow{2}{*}{ Reference } \\
\hline & $\begin{array}{l}\mathrm{V} 3-\mathrm{V} 5 \\
\text { region }\end{array}$ & $\begin{array}{l}\mathrm{V} 6-\mathrm{V} 8 \\
\text { region }\end{array}$ & & \\
\hline ATAD inlet & 80.2 & 50.4 & 56.40 & This study \\
\hline $\begin{array}{l}\text { ATAD Reactor 1A } \\
\text { (after } 4 \text { hours) }\end{array}$ & 50 & 1.53 & 36.56 & This study \\
\hline $\begin{array}{l}\text { ATAD Reactor 1A } \\
\text { (after } 8 \text { hours) }\end{array}$ & 40.5 & 12.67 & 4.05 & This study \\
\hline $\begin{array}{l}\text { ATAD Reactor 1A } \\
\text { (after } 16 \text { hours) }\end{array}$ & 6.61 & 12.67 & 4.05 & This study \\
\hline $\begin{array}{l}\text { Reactor } 2 \mathrm{~A} \\
\text { (after } 4 \text { hours) }\end{array}$ & 140 & 15.9 & 7.2 & This study \\
\hline $\begin{array}{l}\text { Reactor } 2 \mathrm{~A} \\
\text { (after } 23 \text { hours) }\end{array}$ & 113.9 & 62.5 & 9.1 & This study \\
\hline $\begin{array}{l}\text { Biosolids } \\
\text { (after post treatment) }\end{array}$ & 104.4 & 12.1 & 13.6 & This study \\
\hline $\begin{array}{l}\text { Pharmaceutical } \\
\text { activated sludge }\end{array}$ & 25 & - & - & {$[21]$} \\
\hline $\begin{array}{l}\text { Stable nitrifying } \\
\text { reactor }\end{array}$ & 145 & & & {$[21]$} \\
\hline $\begin{array}{l}\text { Municipal activated } \\
\text { sludge }\end{array}$ & 57 & - & - & {$[21]$} \\
\hline Garden soil & 220 & - & - & {$[21]$} \\
\hline Legume rhizosphere & 57 & - & - & {$[21]$} \\
\hline Arctic sea ice & 26 & - & - & {$[21]$} \\
\hline
\end{tabular}

mesophilic sludges (Reactor $1 \mathrm{~A}$, inlet, product) which may be explained by an increased CG content of these amplicons. The DGGE patterns suggest that as the ATAD process proceeds, new bands appear (Figure 1, Lanes 6 and 7) indicative of new species emerging, while certain bands present in the mesophilic sludge samples are also retained indicating that 

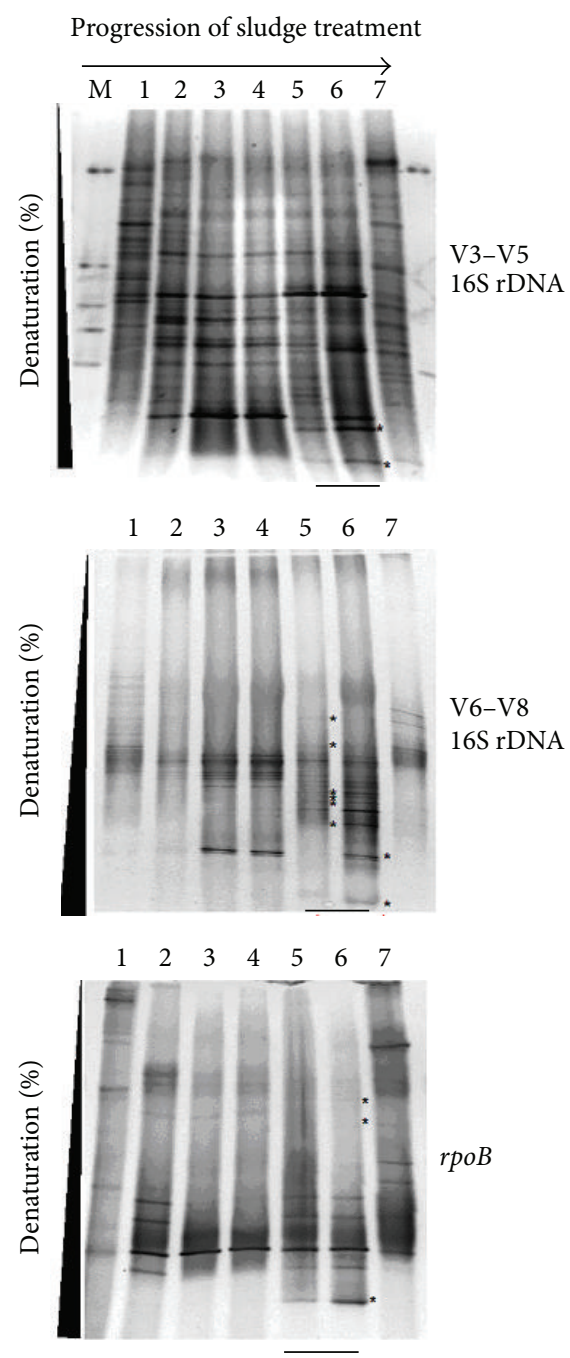

FIGURE 1: Succession of bacterial communities during the ATAD process as monitored by DGGE fingerprints from DNA targets amplified by PCR from directly extracted ATAD sludge DNA. Primers targeted conserved regions of the V3-V5 and V6-V8 regions of the bacterial $16 \mathrm{~S}$ rDNA and $r p o B$ gene sequences. Lane 1: thickened sludge, Lane 2: Reactor 1A (after 4 hours), Lane 3: Reactor 1A (after 8 hours), Lane 4: Reactor 1A (after 16 hours), Lane 5: Reactor 2A (after 4 hours), Lane 6: Reactor 2A (after 23 hours), and Lane 7: product (biosolids after treatment). The pattern for thermophilic sludge (Reactor 2A) is illustrated by the underlying arrows. Unique bands from the thermophilic fingerprints are highlighted with $(*)$ on the right side of the lane. The bar indicates the profile from the thermophilic stage in Reactor 2A.

certain species have adapted to the elevated temperature and $\mathrm{pH}$ conditions in Reactor 2A.

Overall we observed a significant difference between the total microbial communities of influent and thermophilic reactors. The number of bands obtained from thermophilic samples for primers specific to the $\mathrm{V} 3-\mathrm{V} 5$ region of $16 \mathrm{~S} \mathrm{rDNA}$ was higher than that for the V6-V8 region or for $r p o B$ gene (10 as opposed to 22 bands). Dendrograms created for the V6-V8 region showed that the microbial community in the thermophilic reactor at 4 hours and 24 hours can be grouped into distinct clusters (Figure 2) 11 new DGGE bands were observed, while for the $r p o B$ amplicon pool and only two new bands were observed. The numbers of unique bands obtained for the thermophilic stage of ATAD were quantified using the BioNumerics 4.0 software, summarized in Table 3. The number of DGGE patterns obtained for the V3-V5 region for the thermophilic stage was highest with fewer bands observed from the V6-V8 region. This may reflect less variability in amplicons originated from this region resulting in fewer different bands.

The application of moving window analysis, where the differences between profiles were plotted as a function of ATAD process steps (Figure 2), revealed a clear shift in bacterial population richness with the number of dominant and recessive bands for each biomarker varying. Changes in the richness (Rr) within the population as a function of the ATAD treatment steps could be detected for all the primers used (Figure 3). After 16 hours of processing in Reactor $1 \mathrm{~A}$, there was a decline in population richness. Numerical comparison of the DGGE fingerprints for the V6-V8 region $16 \mathrm{~S}$ rDNA amplicons at 4 hours and 23 hours in Reactor $2 \mathrm{~A}$ provides evidence that the community richness is increased, indicating that 4 hours after the feeding within Reactor $2 \mathrm{~A}$, only a few specialized, adapted, and possibly less diverse microbial species are predominant, whereas 23 hours after feeding, the prevailing conditions may support activity and growth of more diverse bacterial species (more diverse DGGE profile). These observations indicate that caution is necessary in the choice of amplicons used in studying such population dynamics. The similarities between the DGGE patterns produced from fingerprints of the various amplicons for each reactor were calculated and visualized as a clustered tree to evaluate the dynamics within the groups of bacteria (Figure 3). Clear differences in bacterial community structure were observed from each point sampled during the ATAD process, which is consistent with suggestions that the process temperature is the driving force for bacterial selection and adaptation. However, dendrograms derived from DGGE fingerprints, for the V3-V5 region indicate that the fingerprint of microorganisms from the thermophilic stage are clustered together with the profile of the community from the mesophilic sludge (Reactor 1A) (Figure 3). This may indicate that the communities are similar or related to a degree and share common bacterial members. The recovered richness $\mathrm{Rr}$ indexes for DGGE fingerprints for each population at different stages of ATAD were found to be influenced by the primer set used for the analysis (Table 4). In the case of community data recovered from thermophilic Reactor 2A, the greatest richness value was obtained using primers for the V3-V5 region of $16 \mathrm{~S}$ rDNA $(\mathrm{Rr}=113.9-104.4)$ and the lowest observed for primers for the $r p o B$ gene $(\mathrm{Rr}=9.1-13.6)$. In comparison to other studies (reviewed in [21]), the richness of the ATAD thermophilic community (Reactor 2A) was less than that for soil ecosystems, which are known to be rich in the number of bacterial lineages, but in a similar range to that observed in the activated sludge [21] This data supports the suggestion that the ATAD thermophilic process presents a selective environment supporting a specialized bacterial community. 


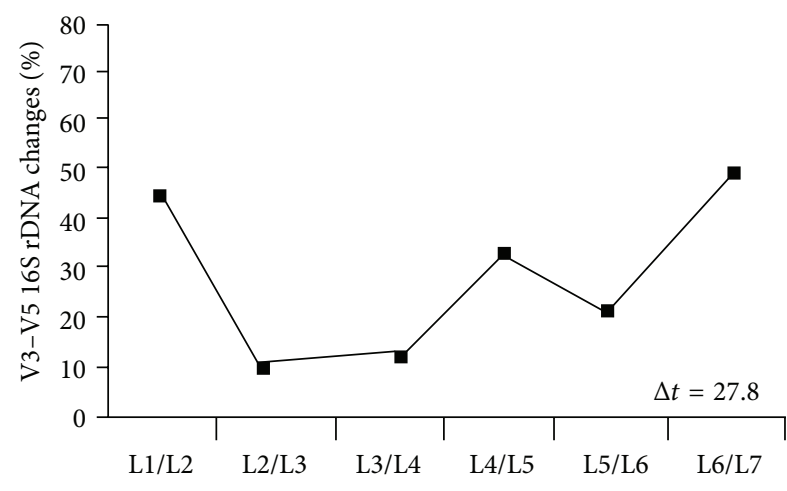

(a)

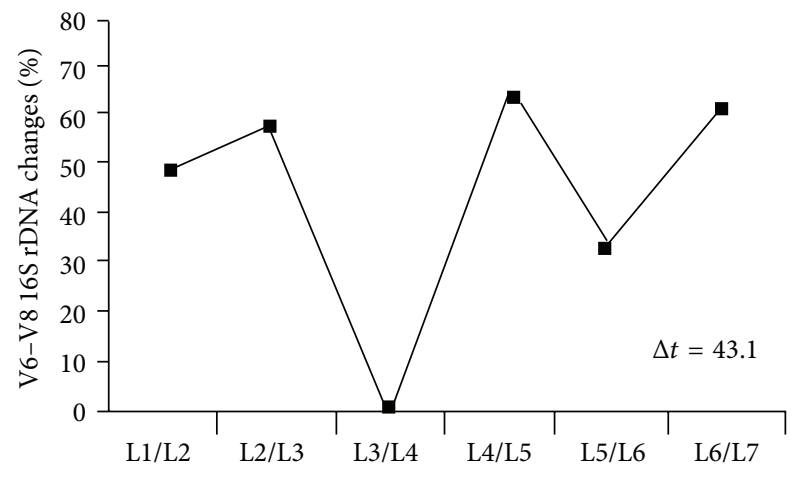

(b)

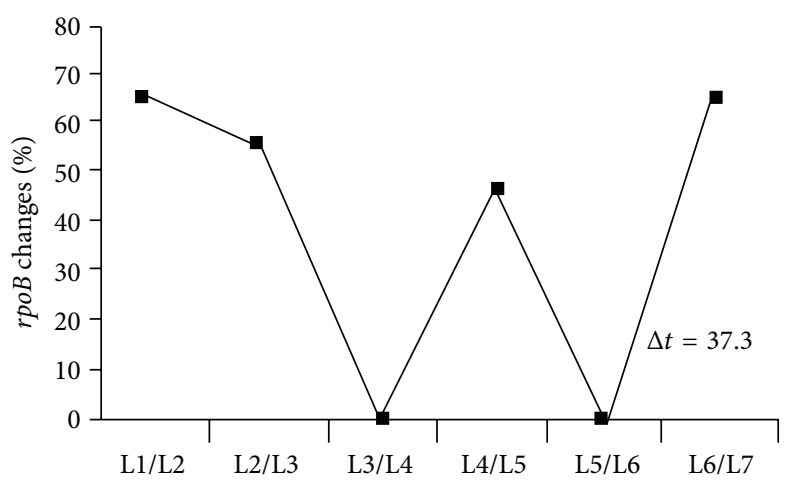

(c)

Figure 2: Moving window analyses (MWA) and rate of change $(\Delta t)$ values to evaluate the level of dynamics of the bacterial community during ATAD treatment. Primer sets were targeted to the V3-V5 and V6-V8 regions of the bacterial $16 \mathrm{~S}$ rDNA and $r p o B$ gene sequences. L1 thickened sludge, L2 Reactor 1A (after 4 hours), L3 Reactor 1A (after 8 hours), L4 Reactor 1A (after 16 hours), L5 Reactor 2A (after 4 hours), L6 Reactor 2A (after 23 hours), and L7 product (biosolids after treatment). Values were calculated as described in Section 2.

\section{Discussion}

The diversity of wastewater microorganisms is an important ecological parameter, which has been mainly expressed using ecological indices such as the Shannon or Simpson indices [50]. While the community diversity and composition are important, the dynamics of microbial communities are also a key issue, as this plays an important role in the functionality and health of a system. Generally, examination of dynamics and perturbation of functionally stable microbial communities has been overlooked in studies of ecosystems and especially wastewater treatment systems. Previous studies on ATAD have focused on the microbial populations at the thermophilic stage $[1,32,51]$ with little attention being paid to how the populations change as a function of process progress and, indeed how, this could be monitored.

Here DGGE of PCR-amplified 16S rDNA and rpoB gene fragments from samples taken from an ATAD treating domestic waste at full scale revealed an active interaction between the physicochemical parameters during the process and the bacterial community. This is consistent with analogous levels of bacterial community dynamics in benchscale thermophilic digestion systems and full-scale treatment systems applied for biodegradation of pharmaceutical waste [1]. Data indicated that the microbial community had a mesophilic origin in the primary and secondary sludge and subsequently adapted to the changing environmental conditions of the ATAD process at elevated temperature and high $\mathrm{pH}$ during the thermophilic stage. This adaptation of the bacterial community leads to a stable process resulting in the pasteurization of ATAD sludge at the thermophilic stage. This adaptive capacity of the bacterial community is a key factor in the overall ATAD process. One of the aims of this study was to determine whether the combination of parameters, such as $\mathrm{pH}$, oxygen availability, and the temperature regime in the ATAD process reactors, would serve as a driving force for the selection of specific active microflora within each reactor. Using PCR-DGGE techniques, we initially evaluated the effect of the methodology on the reliability of the analysis.

A key initial factor was the ability to extract total DNA from the ATAD system such that maximum recovery of the total microbial population would be achieved. Maximum recovery could be achieved by utilizing multiple extraction methods and pooling samples for analysis [31]. There have been many reports of conflicting estimates of microbial diversity due to the extraction protocols [31,52-54], but there have been few applications of multiple extraction techniques and pooling to address the issue. A touchdown PCR technique was applied for amplification [55] using different sets of primers, as such techniques have been considered useful to 

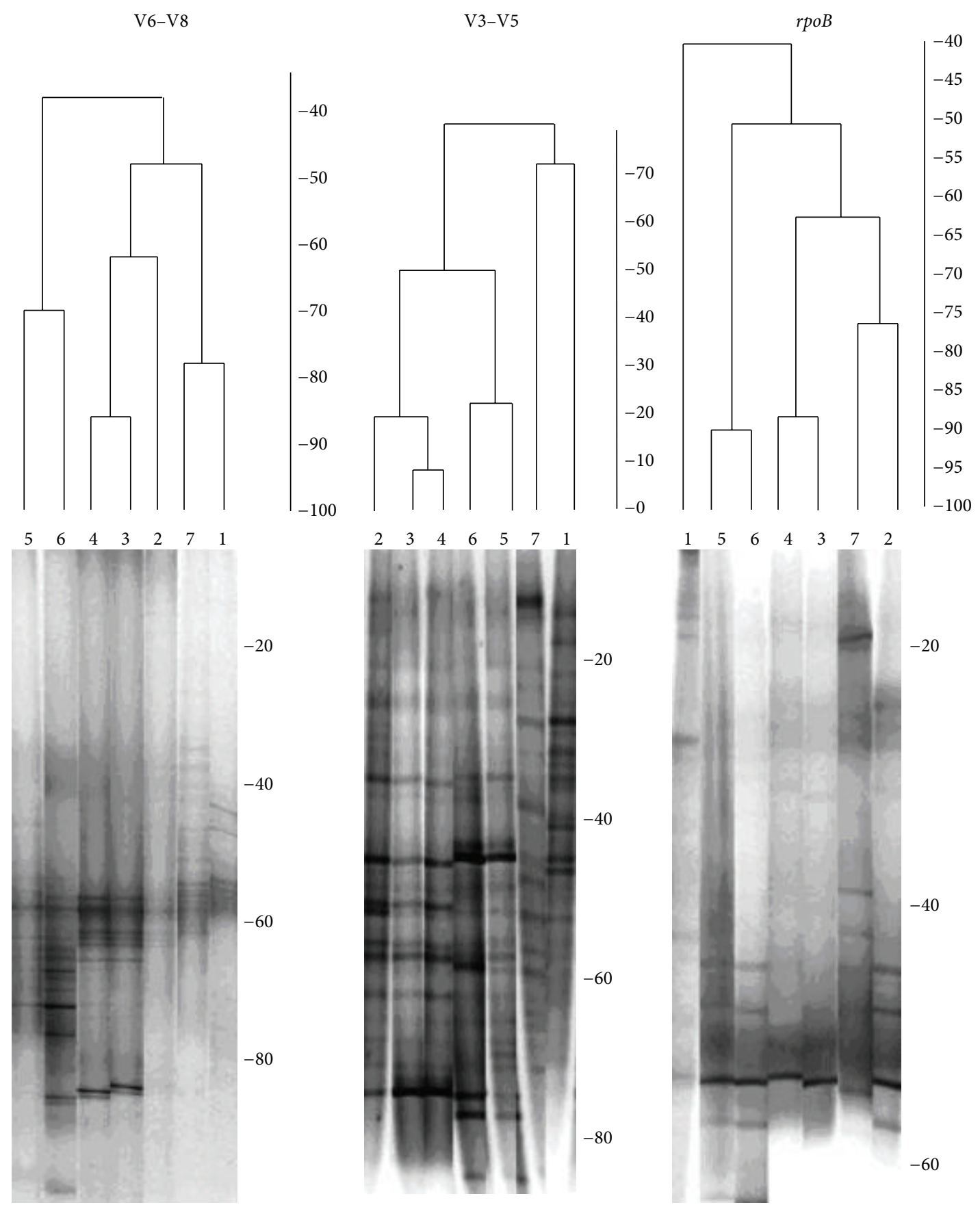

FIGURE 3: UPGMA dendrogram of DGGE profiles of amplified $16 \mathrm{~S}$ rDNA of the total bacterial community from ATAD sludge obtained at different stages of the ATAD process using BioNumerics 4.0 software advanced analysis package. The fingerprints were obtained with primers amplifing the V6-V8 and V3-V5 regions of $16 \mathrm{~S}$ rDNA and the $r p o B$ gene. The cluster tree images are aligned alongside. Lane 1: thickened sludge, Lane 2: Reactor 1A (after 4 hours), Lane 3: Reactor 1A (after 8 hours), Lane 4: Reactor 1A (after 16 hours), Lane 5: Reactor 2A (after 4 hours), Lane 6: Reactor 2A (after 23 hours), and Lane 7: product (biosolids after treatment).

avoid the amplification of spurious DNA fragments (nonrDNA fragments and/or fragments of improper size) [55].

Kingdom specific probes were initially employed and detected fungal sequences at inlet and at the early stages within mesophilic Reactor 1A. Fungal sequences were not detected at later stages in Reactor $1 \mathrm{~A}$, which can be characterized by a $\mathrm{pH}$ rise between $\mathrm{pH} 8.3$ and 9 and a temperature rise to $53-55^{\circ} \mathrm{C}$ (Table 2). The alkaline $\mathrm{pH}$ of $8.3-9$ and the high temperature are not supportive environments for Eukarya or Fungal species and are possible reasons why neither was detected at the thermophilic stage. Aeration in Reactor 1A and Reactor 2A is probably a factor responsible for the inability to detect Archaeal species although these were present at inlet. Bacterial species were detected at all stages 
and were in fact the dominant kingdom in thermophilic Reactor 2A.

Although there are numerous reports [28, 56-59] of using PCR-DGGE to examine microbial diversity, the quality of the information obtained is impacted by the choice of probe, specifically the type of gene used for analysis or that if using the 16S rDNA gene, the $\mathrm{V}$ region(s) chosen. Comparison of nucleotide sequences has shown that there are regions of rDNA sequences that are highly conserved between all organisms and other regions that vary to different degrees. The variability in these regions increases as the evolutionary distance between two organisms increases, which provides a means to determine phylogenetic relationships and to distinguish microorganisms from one another [60]. Here, three primer sets were chosen because they have been used in a number of studies for the characterization of microbial communities $[20,39,61]$. For thermophilic aerobic ecosystems such as ATAD little previous information was available hence, two V-region-specific primers to the $16 \mathrm{~S}$ rDNA gene and primers to the $r p o B$ gene were examined. The results presented on the ATAD (Figure 2 and Table 4) sludge community DNA samples indicated that the genetic template chosen for amplification and analysis by DGGE can influence the recovery of richness and diversity indices, as well as the ability of the DGGE method to detect the changes within the community. The degree of variability of the chosen genetic marker within the community and the degree of dissimilarity between the nucleotide sequences of bacterial members inhabiting ATAD sludge at various treatment stages are the most decisive factors in determining the success of ecological monitoring (Figure 1). Another factor that needs optimization is the separation parameters within DGGE, which include gradient range and electrophoresis parameters such as voltage and time. Such parameters have received limited attention for mesophilic communities, and no data is available for parameter optimization for thermophilic bacterial communities where the GC content of DNA increases and can potentially affect DGGE fingerprinting methods. Three different primer sets were utilized to amplify nonoverlapping regions of the 16S rDNA gene V3 to V5 (set A), V6-V8 (set B) and the rpoB gene (set C). PCR amplification and DGGE fingerprint analysis of the ATAD samples via $\mathrm{V} 3$ to $\mathrm{V} 5$ region and $\mathrm{V} 6-\mathrm{V} 8$ region produced superior dynamic profiles with V6-V8 profiles being easier to compare between sampling sites. Variations (Figure 2) within the DGGE fingerprint for V3-V5 and V6-V8 amplicons were observed at sampling sites, such as Reactor $2 \mathrm{~A}$ at 4 and 23 hours, indicating the possible development of microcosms with differing predominant species and diversity indicative of temperature, substrate [30], and oxygen solubility changes within the thermophilic reactor. Primer sets for the V6-V8 region produced the highest number of thermophilic phylotypes, whereas the V3V5 region primers resulted in the recovery of the highest number of phylotypes from the less thermophilic environments at earlier stages of the ATAD process. This suggested that the latter pool may be more genetically variable, and pattern differences may be expected because GC content and nucleotide conservation are not constant for the length of the gene $[39,62]$. The fingerprints obtained by the DGGE method were used to examine the similarity of a group of samples taken at different process stages and calculated from binary matrices (Figure 3). As the intensity of DGGE bands can be or influenced by small PCR errors or the DNA extraction efficiency of rare templates, the analysis of intensity matrices during comparison was not utilized. The choice of fragments used for amplification and DGGE profiling influenced how profiles were grouped together and the degree of similarity observed between ATAD sludge samples. The V6-V8 pool (setB) of $16 \mathrm{~S}$ rDNA amplicons was able to cluster the community not only in relation to the changes in temperature parameters, but in correlating nutrient availability and stage of treatment (Figure 3, Table 4). Set A primers (V3-V5 region) amplified a smaller 16S rDNA fragment which contained more sequence variability within the microbial community and was more useful in profiling variability within the mesophilic sludge (Reactor 1A). In the thermophilic sludge, set B (V6-V8) primers gave more discriminating profiles. These data suggested that set $\mathrm{B}(\mathrm{V} 6-\mathrm{V} 8)$ primers would be more useful for further ecological monitoring and analysis of the thermophilic microbial communities.

It has been proposed [21] that in addition to standard DGGE gel comparison, additional statistical analyses could be applied for comparative purposes. A statistical approach was utilized in comparing ATAD microbial communities using a moving window correlation (Figure 2). The principle of moving window correlation, a more quantitative measure to evaluate diversity and evolutionary shifts over processing time, can generally be used to monitor the effect of process evolution and changes in ecological parameters on population variability within or between systems. This can be used to define a stability rate for the microbial community under investigation, and as opposed to principal component analysis, multidimensional scaling, cluster analysis, and diversity indices, this technique includes a time-based analysis of the DGGE data. The capacity of this DGGE analysis to monitor the changes and stabilization of the microbial community at various ATAD treatment steps over time was evaluated by comparing the results obtained with the measured variability of DGGE community profiles obtained with various genetic biomarkers (Figure 2). This latter method was based on the within-gel variability of DGGE analysis obtained for each verified pool of three biomarkers and a stability criterion applied to evaluate the results. Based on the coefficients obtained, the stability profiles for the different reactors and primer sets were quantitatively evaluated and compared to each other. A clear change in population richness was obtained for each biomarker however, the degree of change was variable for each marker and different markers showed variable utilities depending on the process stage and whether it was thermophilic or not (Table 4). The $r p o B$ marker appeared to be least informative during our ATAD analysis (Table 5). Changes in richness were also monitored as proposed [21] and indicated (Figure 2) that the V3-V5 marker was most informative at the mesophilic/thermophilic interface, whereas the V6-V8 was more useful during the thermophilic stage between 4 and $23 \mathrm{hrs}$ of thermophilic treatment. Primer sets for the V6-V8 region produced the highest number of thermophilic phylotypes, whereas the V3-V5 region primers 
TABLE 5: Comparison of the efficiency of different primer sets to monitor diversity of the bacterial community inhabiting the elevated temperature reactor (ATAD Reactor $2 \mathrm{~A}$ ) at various times of reactor operation (after 4 hours and 23 hours).

\begin{tabular}{|c|c|c|c|c|c|}
\hline \multirow{3}{*}{ Genetic biomarker } & \multicolumn{5}{|c|}{ DGGE profile analysis of $\mathrm{PCR}$ product } \\
\hline & \multicolumn{2}{|c|}{ Diversity $^{\mathrm{a}}$} & \multicolumn{2}{|c|}{ Number unique band } & \multirow{2}{*}{$\begin{array}{l}\text { Total numbers of the unique bands } \\
\text { appearing during operation of Reactor } 2 \mathrm{~A}\end{array}$} \\
\hline & $\begin{array}{c}\text { Reactor } 2 \\
(4 \mathrm{hrs})\end{array}$ & $\begin{array}{c}\text { Reactor } 2 \\
(23 \mathrm{hrs})\end{array}$ & $\begin{array}{c}\text { Reactor } 2 \\
(4 \mathrm{hrs})\end{array}$ & $\begin{array}{c}\text { Reactor } 2 \\
(23 \mathrm{hrs})\end{array}$ & \\
\hline \multicolumn{6}{|l|}{ 16S rRNA gene } \\
\hline V3-V5 & 19 & 18 & 5 & 2 & 7 \\
\hline V6-V8 & 14 & 12 & 5 & 6 & 11 \\
\hline rpoB & 4 & 6 & 1 & 1 & 2 \\
\hline
\end{tabular}

${ }^{\mathrm{a}}$ Total number of bands detected on a DGGE lane.

resulted in recovery of the highest number of phylotypes from the less thermophilic environments at earlier stages of the ATAD process (Table 5). This suggested that the latter pool may be more genetically variable, and pattern differences may be expected because GC content and nucleotide conservation are not constant for the length of the gene $[39,62]$. Therefore, unless the proper primer sets are determined for DGGE monitoring at thermophilic stages, errors in interpretation and conclusions can be made in relation to the diversity present, and this may indeed be a principle when DGGE is used in process monitoring in general. Here, the V6V8 analysis indicated the presence of increased diversity at the thermophilic stage and not a decline in diversity as previously reported for ATAD treating pharmaceutical waste [1]. Analysis of the sludge composition in Reactor 2A (using V6-V8 primers) clearly indicated an interaction between the physicochemical features of the reactors and the microbial community present and suggested that depletion of nutrients and carbon sources may serve as a dominant factor for population changes at later stages of ATAD thermophilic treatment $[30,46]$. These data provide support for the hypothesis [51] that temperature is not the only factor acting as an environmental stressor in ATAD wastewater treatment systems and suggest that the thermophilic community is highly adaptable to changes in process conditions and sludge characteristics. This analysis highlights previous concerns $[28,57,58]$ that results of DGGE-based community structure analyses should be interpreted cautiously and experimental settings for new environmental samples need to be optimized carefully. The elevated GC content of DNA in thermophilic organisms is known as an adaptive mechanism to increased temperatures, and this is observed in the patterns obtained from the thermophilic stages of the ATAD process. DGGE, once optimized, is thus a promising way of investigating bacterial community structure and dynamics within aerobic thermophilic communities and is an aid to monitoring process health. However, as only partial sequences are generated from DGGE bands, this may limit taxonomical and species assignment. Unlike the $16 \mathrm{~S}$ rDNA gene, where multiple copies can exist within genomes which complicate diversity assessment, the gene for the beta subunit of the RNA polymerase, $r p o B$, is a single copy gene and offers advantages on occasion. When the $r p o B$ gene was amplified, fewer DGGE bands were observed which may be reflective of the close GC content of the microbial population in Reactor $2 \mathrm{~A}$ or the close sequence similarity of this select population. In either event, its use was less discriminating than the $16 \mathrm{~S}$ rDNA primers for aerobic thermophilic populations.

\section{Conclusion}

The overall aim of the ATAD process is to generate a pasteurized, stabilized sludge suitable for classification as a Class A biosolid. Given that the driving force is heat generated by a thermophilic biodegradative population, systems such as PCR-DGGE may prove useful in monitoring the optimal characteristics of the system. The protocols described here, upon optimization, can easily be applied for routine monitoring of bacterial populations within thermophilic niches such as ATAD waste treatment and can be of use in monitoring the process health and indeed stability of the process as a function of time. Use of $16 \mathrm{~S}$ rDNA sequencing of excised DGGE bands can prove useful for further phylogenetic analyses of such ATAD systems, and these studies are underway [32].

\section{Conflict of Interests}

The authors wish to state that there is either conflict of interests in the use of equipment or use of trademarked software during this work nor is there any conflict of interests related to financial gain of the authors as a consequence of this work.

\section{Acknowledgments}

This work was financially supported by a collaborative research grant from the Higher Education Authority (HEA) under PRTLI 4. The authors acknowledge the staff of the Killarney ATAD wastewater treatment facility for their help and assistance during sampling.

\section{References}

[1] T. M. Lapara, C. H. Nakatsu, L. Pantea, and J. E. Alleman, "Phylogenetic analysis of bacterial communities in mesophilic and thermophilic bioreactors treating pharmaceutical wastewater," Applied and Environmental Microbiology, vol. 66, no. 9, pp. 3951-3959, 2000. 
[2] N. M. Layden, D. S. Mavinic, H. G. Kelly, R. Moles, and J. Bartlett, "Autothermal thermophilic aerobic digestion (ATAD) - part I: review of origins, design, and process operation," Journal of Environmental Engineering and Science, vol. 6, no. 6, pp. 665-678, 2007.

[3] N. M. Layden, H. G. Kelly, D. S. Mavinic, R. Moles, and J. Bartlett, "Autothermal thermophilic aerobic digestion (ATAD) - part II: review of research and full-scale operating experiences," Journal of Environmental Engineering and Science, vol. 6, no. 6, pp. 679-690, 2007.

[4] U.S. EPA, United States Environmental Protection AgencyStandards for the Use or Disposal of Sewage Sludge, vol. 58, Federal Register Environmental Protection Agency, Washington, DC, USA, 1994, 40 CFR Parts 257, 403, 503.

[5] U.S. EPA, "Report EPA/625/10-90/007 United States Environmental Protection Agency-autothermal thermophilic aerobic digestion of municipal wastewater sludge," Environmental Protection Agency, Washington, DC, USA, 1990.

[6] P. Burt, S. F. Morgan, B. N. Dancer, and J. C. Fry, "Microbial populations and sludge characteristics in thermophilic aerobic sewage sludge digestion," Applied Microbiology and Biotechnology, vol. 33, no. 6, pp. 725-730, 1990.

[7] A. V. Piterina, J. Bartlett, and T. J. Pembroke, "Evaluation of the removal of indicator bacteria from domestic sludge processed by autothermal thermophilic aerobic digestion (ATAD)," International Journal of Environmental Research and Public Health, vol. 7, no. 9, pp. 3422-3441, 2010.

[8] P. Chesson, "Mechanisms of maintenance of species diversity," Annual Review of Ecology and Systematics, vol. 31, pp. 343-366, 2000.

[9] G. Collins, T. Mahony, and V. O’Flaherty, "Stability and reproducibility of low-temperature anaerobic biological wastewater treatment," FEMS Microbiology Ecology, vol. 55, no. 3, pp. 449458, 2006.

[10] D. Jenkins, "From total suspended solids to molecular biology tools-a personal view of biological wastewater treatment process population dynamics," Water Environment Research, vol. 80 , no. 8 , pp. $677-687,2008$.

[11] J. L. Sanz and T. Köchling, "Molecular biology techniques used in wastewater treatment: an overview," Process Biochemistry, vol. 42, no. 2, pp. 119-133, 2007.

[12] A. V. Piterina, C. MacCausland, J. Bartlett, and J. T. Pembroke, "Microbial ecology of autothermal aerobic digestion (ATAD): diversity, dynamics and activity of bacterial communities involved in treatment of municipal wastewater," in Modern Multidisciplinary Applied Microbiology: Exploiting Microbes and Their Interactions, A. Mendez-Vilas, Ed., pp. 526-535, WileyVCH, Weinheim, Germany, 2006.

[13] B. P. McIlhatton, C. Keating, M. D. Curran et al., "Identification of medically important pathogenic fungi by reference strandmediated conformational analysis (RSCA)," Journal of Medical Microbiology, vol. 51, no. 6, pp. 468-478, 2002.

[14] B. La Scola, Z. Zeaiter, A. Khamis, and D. Raoult, "Genesequence-based criteria for species definition in bacteriology: the Bartonella paradigm," Trends in Microbiology, vol. 11, no. 7, pp. 318-321, 2003.

[15] C. B. Blackwood, A. Oaks, and J. S. Buyer, "Phylum- and classspecific PCR primers for general microbial community analysis," Applied and Environmental Microbiology, vol. 71, no. 10, pp. 6193-6198, 2005.

[16] E. O. Casamayor, R. Massana, S. Benlloch et al., "Changes in archaeal, bacterial and eukaryal assemblages along a salinity gradient by comparison of genetic fingerprinting methods in a multipond solar saltern," Environmental Microbiology, vol. 4, no. 6, pp. 338-348, 2002.

[17] I. M. Head, J. R. Saunders, and R. W. Pickup, "Microbial evolution, diversity, and ecology: a decade of ribosomal RNA analysis of uncultivated microorganisms," Microbial Ecology, vol. 35, no. 1, pp. 1-21, 1998.

[18] P. Normand, C. Ponsonnet, X. Nesme, M. Neyra, and P. Simonet, "ITS analysis of prokaryotes," in Molecular Microbial Ecology Manual, pp. 1-12, Kluwer Academic, Dodrecht, The Netherlands, 1996.

[19] G. Muyzer, E. C. de Waal, and A. G. Uitterlinden, "Profiling of complex microbial populations by denaturing gradient gel electrophoresis analysis of polymerase chain reaction-amplified genes coding for $16 \mathrm{~S}$ rRNA," Applied and Environmental Microbiology, vol. 59, no. 3, pp. 695-700, 1993.

[20] G. Muyzer, S. Hottentrager, A. Teske, and C. Wawer, "Denaturing gradient gel electrophoresis of PCR-amplified 16S rDNAa new molecular approach to analyse the genetic diversity of mixed microbial communities," in Molecular Microbial Ecology Manual, G. A. Kowalchuk, F. J. Bruijn, I. M. Head, A. D. Akkermans, and J. D. van Elsas, Eds., pp. 1-23, Kluwer Academic, Nowell, Mass, USA, 1996.

[21] M. Marzorati, L. Wittebolle, N. Boon, D. Daffonchio, and W. Verstraete, "How to get more out of molecular fingerprints: practical tools for microbial ecology," Environmental Microbiology, vol. 10, no. 6, pp. 1571-1581, 2008.

[22] A. E. McCaig, L. A. Glover, and J. I. Prosser, "Numerical analysis of grassland bacterial community structure under different land management regimens by using $16 \mathrm{~S}$ ribosomal DNA sequence data and denaturing gradient gel electrophoresis banding patterns," Applied and Environmental Microbiology, vol. 67, no. 10, pp. 4554-4559, 2001.

[23] H. Y. Tsen, C. K. Lin, and W. R. Chi, "Development and use of 16S rRNA gene targeted PCR primers for the identification of Escherichia coli cells in water," Journal of Applied Microbiology, vol. 85, no. 3, pp. 554-560, 1998.

[24] I. Dahllöf, H. Baillie, and S. Kjelleberg, "rpoB-based microbial community analysis avoids limitations inherent in 16S rRNA gene intraspecies heterogeneity," Applied and Environmental Microbiology, vol. 66, no. 8, pp. 3376-3380, 2000.

[25] G. C. Wang and Y. Wang, "Frequency of formation of chimeric molecules as a consequence of PCR coamplification of $16 \mathrm{~S}$ rRNA genes from mixed bacterial genomes," Applied and Environmental Microbiology, vol. 63, no. 12, pp. 4645-4650, 1997.

[26] K. Watanabe, Y. Kodama, and S. Harayama, "Design and evaluation of PCR primers to amplify bacterial 16S ribosomal DNA fragments used for community fingerprinting," Journal of Microbiological Methods, vol. 44, no. 3, pp. 253-262, 2001.

[27] J. M. Gonzalez, M. C. Portillo, and C. Saiz-Jimenez, "Multiple displacement amplification as a pre-polymerase chain reaction (pre-PCR) to process difficult to amplify samples and low copy number sequences from natural environments," Environmental Microbiology, vol. 7, no. 7, pp. 1024-1028, 2005.

[28] Z. Yu, R. García-González, F. L. Schanbacher, and M. Morrison, "Evaluations of different hypervariable regions of archaeal 16S rRNA genes in profiling of methanogens by Archaea-specific PCR and denaturing gradient gel electrophoresis," Applied and Environmental Microbiology, vol. 74, no. 3, pp. 889-893, 2008.

[29] J. Ning, J. Liebich, M. Kästner, J. Zhou, A. Schäffer, and P. Burauel, "Different influences of DNA purity indices and quantity on PCR-based DGGE and functional gene microarray in 
soil microbial community study," Applied Microbiology and Biotechnology, vol. 82, no. 5, pp. 983-993, 2009.

[30] A. V. Piterina, J. Barlett, and J. T. Pembroke, ${ }^{13}$ C-NMR assessment of the pattern of organic matter transformation during domestic wastewater treatment by autothermal aerobic digestion (ATAD)," International Journal of Environmental Research and Public Health, vol. 6, no. 8, pp. 2288-2306, 2009.

[31] A. V. Piterina, J. Bartlett, and J. T. Pembroke, "Molecular analysis of bacterial community DNA in sludge undergoing autothermal thermophilic aerobic digestion (ATAD): pitfalls and improved methodology to enhance diversity recovery," Diversity, vol. 2, no. 4, pp. 505-526, 2010.

[32] A. V. Piterina, J. Bartlett, and J. T. Pembroke, "Phylogenetic analysis of the bacterial community in a full scale autothermal thermophilic aerobic digester (ATAD) treating mixed domestic wastewater sludge for land spread," Water Research, vol. 46, no. 8, pp. 2488-2504, 2012.

[33] S. G. Acinas, L. A. Marcelino, V. Klepac-Ceraj, and M. F. Polz, "Divergence and redundancy of $16 \mathrm{~S}$ rRNA sequences in genomes with multiple rrn operons," Journal of Bacteriology, vol. 186, no. 9, pp. 2629-2635, 2004.

[34] J. K. Brons and J. D. van Elsas, "Analysis of bacterial communities in soil by use of denaturing gradient gel electrophoresis and clone libraries, as influenced by different reverse primers," Applied and Environmental Microbiology, vol. 74, no. 9, pp. 27172727, 2008.

[35] M. C. Hansen, T. Tolker-Nielsen, M. Givskov, and S. Molin, "Biased 16S rDNA PCR amplification caused by interference from DNA flanking the template region," FEMS Microbiology Ecology, vol. 26, no. 2, pp. 141-149, 1998.

[36] O. Sánchez, J. M. Gasol, R. Massana, J. Mas, and C. Pedrós-Alió, "Comparison of different denaturing gradient gel electrophoresis primer sets for the study of marine bacterioplankton communities," Applied and Environmental Microbiology, vol. 73, no. 18, pp. 5962-5967, 2007.

[37] H. Sekiguchi, N. Tomioka, T. Nakahara, and H. Uchiyama, "A single band does not always represent single bacterial strains in denaturing gradient gel electrophoresis analysis," Biotechnology Letters, vol. 23, no. 15, pp. 1205-1208, 2001.

[38] J. Brosius, T. J. Dull, D. D. Sleeter, and H. F. Noller, "Gene organization and primary structure of a ribosomal RNA operon from Escherichia coli," Journal of Molecular Biology, vol. 148, no. 2, pp. 107-127, 1981.

[39] U. Nübel, B. Engelen, A. Felsre et al., "Sequence heterogeneities of genes encoding $16 \mathrm{~S}$ rRNAs in Paenibacillus polymyxa detected by temperature gradient gel electrophoresis," Journal of Bacteriology, vol. 178, no. 19, pp. 5636-5643, 1996.

[40] S. G. Acinas, R. Sarma-Rupavtarm, V. Klepac-Ceraj, and M. F. Polz, "PCR-induced sequence artifacts and bias: insights from comparison of two 16s rRNA clone libraries constructed from the same sample," Applied and Environmental Microbiology, vol. 71, no. 12, pp. 8966-8969, 2005.

[41] V. Farrelly, F. A. Rainey, and E. Stackebrandt, "Effect of genome size and rrn gene copy number on PCR amplification of $16 \mathrm{~S}$ rRNA genes from a mixture of bacterial species," Applied and Environmental Microbiology, vol. 61, no. 7, pp. 2798-2801, 1995.

[42] D. Amikam, S. Razin, and G. Glaser, "Ribosomal RNA genes in mycoplasma," Nucleic Acids Research, vol. 10, no. 14, pp. 42154222, 1982.
[43] G. B. Fogel, C. R. Collins, J. Li, and C. F. Brunk, "Prokaryotic genome size and SSU rDNA copy number: estimation of microbial relative abundance from a mixed population," Microbial Ecology, vol. 38, no. 2, pp. 93-113, 1999.

[44] L. D. Crosby and C. S. Criddle, "Understanding bias in microbial community analysis techniques due to rrn operon copy number heterogeneity," BioTechniques, vol. 34, no. 4, pp. 790794, 2003.

[45] A. V. Piterina and J. T. Pembroke, "Preparation and analysis of environmental DNA: optimisation of techniques for phylogenetic analysis of ATAD sludge," in Communicating Current Research and Educational Topics and Trends in Applied Microbiology, A. Mendez-Vilas, Ed., John Wiley \& Sons, London, UK, 2010.

[46] A. V. Piterina, J. Bartlett, and J. T. Pembroke, "Morphological characterisation of ATAD thermophilic sludge; sludge ecology and settleability," Water Research, vol. 45, no. 11, pp. 3427-3438, 2011.

[47] M. F. Polz and C. M. Cavanaugh, "Bias in template-to-product ratios in multitemplate PCR," Applied and Environmental Microbiology, vol. 64, no. 10, pp. 3724-3730, 1998.

[48] J. Sambrook and D. Russel, Molecular Cloning: A Laboratory Manual, Cold Spring Harbor Laboratory Press, Cold Spring Harbor, NY, USA, 3rd edition, 2000.

[49] S. O. Byun, Q. Fang, H. Zhou, and J. G. H. Hickford, "An effective method for silver-staining DNA in large numbers of polyacrylamide gels," Analytical Biochemistry, vol. 385, no. 1, pp. 174-175, 2009.

[50] A. E. Magurran, Ecological Diversity and Its Measurement, Princeton University Press, Princeton, NJ, USA, 1988.

[51] P. Juteau, D. Tremblay, R. Villemur, J. Bisaillon, and R. Beaudet, "Analysis of the bacterial community inhabiting an aerobic thermophilic sequencing batch reactor (AT-SBR) treating swine waste," Applied Microbiology and Biotechnology, vol. 66, no. 1, pp. 115-122, 2004.

[52] J. R. de Lipthay, C. Enzinger, K. Johnsen, J. Aamand, and S. J. Sørensen, "Impact of DNA extraction method on bacterial community composition measured by denaturing gradient gel electrophoresis," Soil Biology and Biochemistry, vol. 36, no. 10, pp. 1607-1614, 2004.

[53] D. F. Xing and N. Q. Ren, "Common problems in the analyses of microbial community by denaturing gradient gel electrophoresis (DGGE)," Wei Sheng Wu Xue Bao, vol. 46, no. 2, pp. 331-335, 2006.

[54] P. Luo, C. Hu, L. Zhang, C. Ren, and Q. Shen, "Effects of DNA extraction and universal primers on 16S rRNA gene-based DGGE analysis of a bacterial community from fish farming water," Chinese Journal of Oceanology and Limnology, vol. 25, no. 3, pp. 310-316, 2007.

[55] D. J. Korbie and J. S. Mattick, "Touchdown PCR for increased specificity and sensitivity in PCR amplification," Nature Protocols, vol. 3, no. 9, pp. 1452-1456, 2008.

[56] A. Schmalenberger, F. Schwieger, and C. C. Tebbe, "Effect of primers hybridizing to different evolutionarily conserved regions of the small-subunit rRNA gene in PCR-based microbial community analyses and genetic profiling," Applied and Environmental Microbiology, vol. 67, no. 8, pp. 3557-3563, 2001.

[57] Z. Yu and M. Morrison, "Comparisons of different hypervariable regions of rrs genes for use in fingerprinting of microbial communities by PCR-denaturing gradient gel electrophoresis," Applied and Environmental Microbiology, vol. 70, no. 8, pp. 4800-4806, 2004. 
[58] P. J. Shi, Y. G. Bai, T. Z. Yuan, B. Yao, and Y. L. Fan, "Use of rpoB and $16 \mathrm{~S}$ rDNA genes to analyze rumen bacterial diversity of goat using PCR and DGGE," Wei Sheng Wu Xue Bao, vol. 47, no. 2, pp. 285-289, 2007.

[59] P. M. Lorbeg, A. C. Majhenič, and I. Rogelj, "Evaluation of different primers for PCR-DGGE analysis of cheese-associated enterococci," Journal of Dairy Research, vol. 76, no. 3, pp. 265271, 2009.

[60] C. R. Woese, "Bacterial evolution," Microbiological Reviews, vol. 51, no. 2, pp. 221-271, 1987.

[61] A. Felske, B. Engelen, U. Nübel, and H. Backhaus, "Direct ribosome isolation from soil to extract bacterial rRNA for community analysis," Applied and Environmental Microbiology, vol. 62, no. 11, pp. 4162-4167, 1996.

[62] R. A. Clayton, G. Sutton, P. S. Hinkle Jr., C. Bult, and C. Fields, "Intraspecific variation in small-subunit rRNA sequences in GenBank: why single sequences may not adequately represent prokaryotic taxa," International Journal of Systematic Bacteriology, vol. 45, no. 3, pp. 595-599, 1995.

[63] D. J. Lane, "16S/23S rRNA sequencing," in Nucleic Acid Techniques in Bacterial Systematics, E. Stackebrant and M. Goodfellow, Eds., pp. 115-175, John Wiley \& Sons, London, UK, 1991.

[64] N. Bano, S. Ruffin, B. Ransom, and J. T. Hollibaugh, "Phylogenetic composition of Arctic Ocean archaeal assemblages and comparison with antarctic assemblages," Applied and Environmental Microbiology, vol. 70, no. 2, pp. 781-789, 2004.

[65] E. J. van Hannen, G. Zwart, M. P. van Agterveld, H. J. Gons, J. Ebert, and H. J. Laanbroek, "Changes in bacterial and eukaryotic community structure after mass lysis of filamentous cyanobacteria associated with viruses," Applied and Environmental Microbiology, vol. 65, no. 2, pp. 795-801, 1999. 

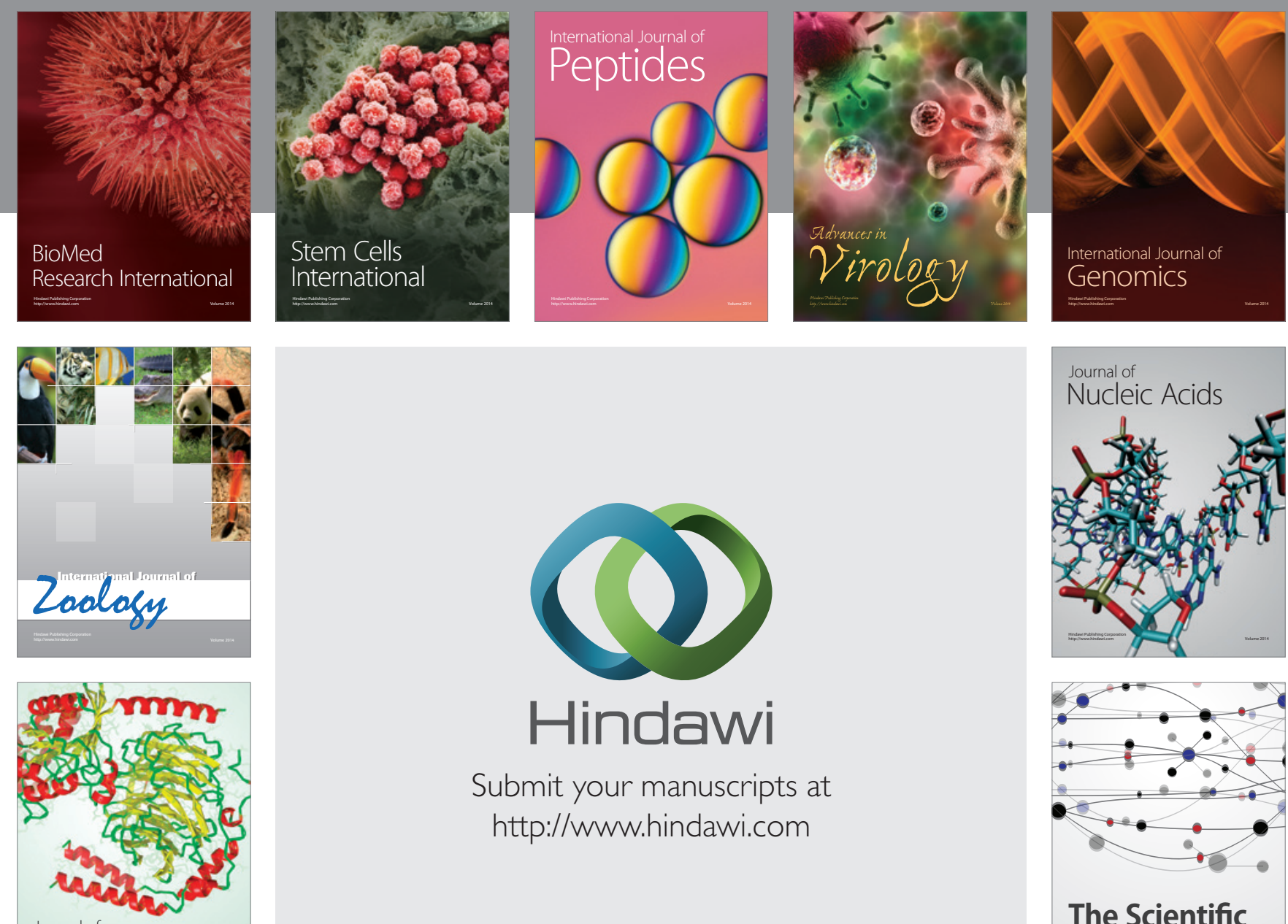

Submit your manuscripts at

http://www.hindawi.com

Journal of
Signal Transduction
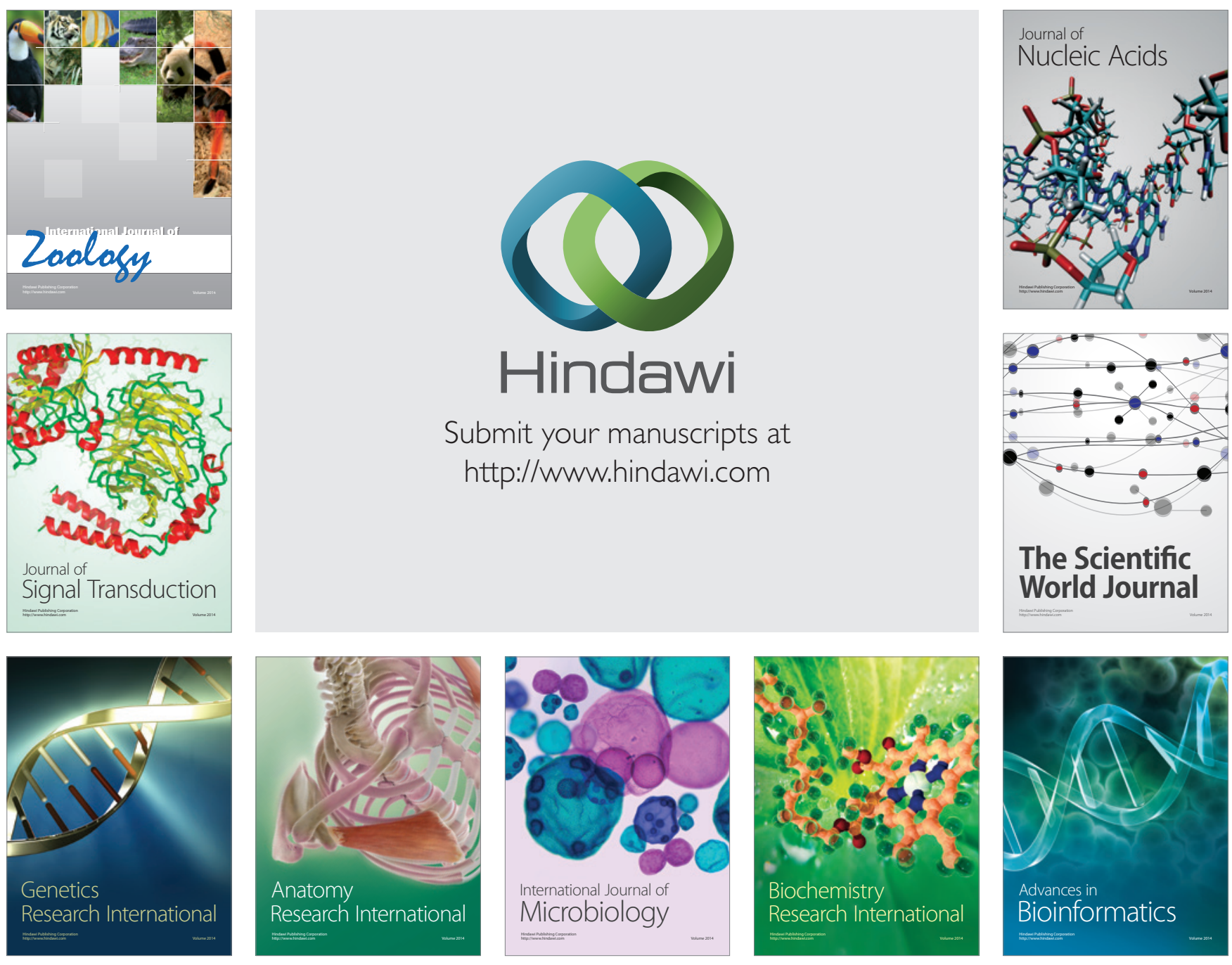

The Scientific World Journal
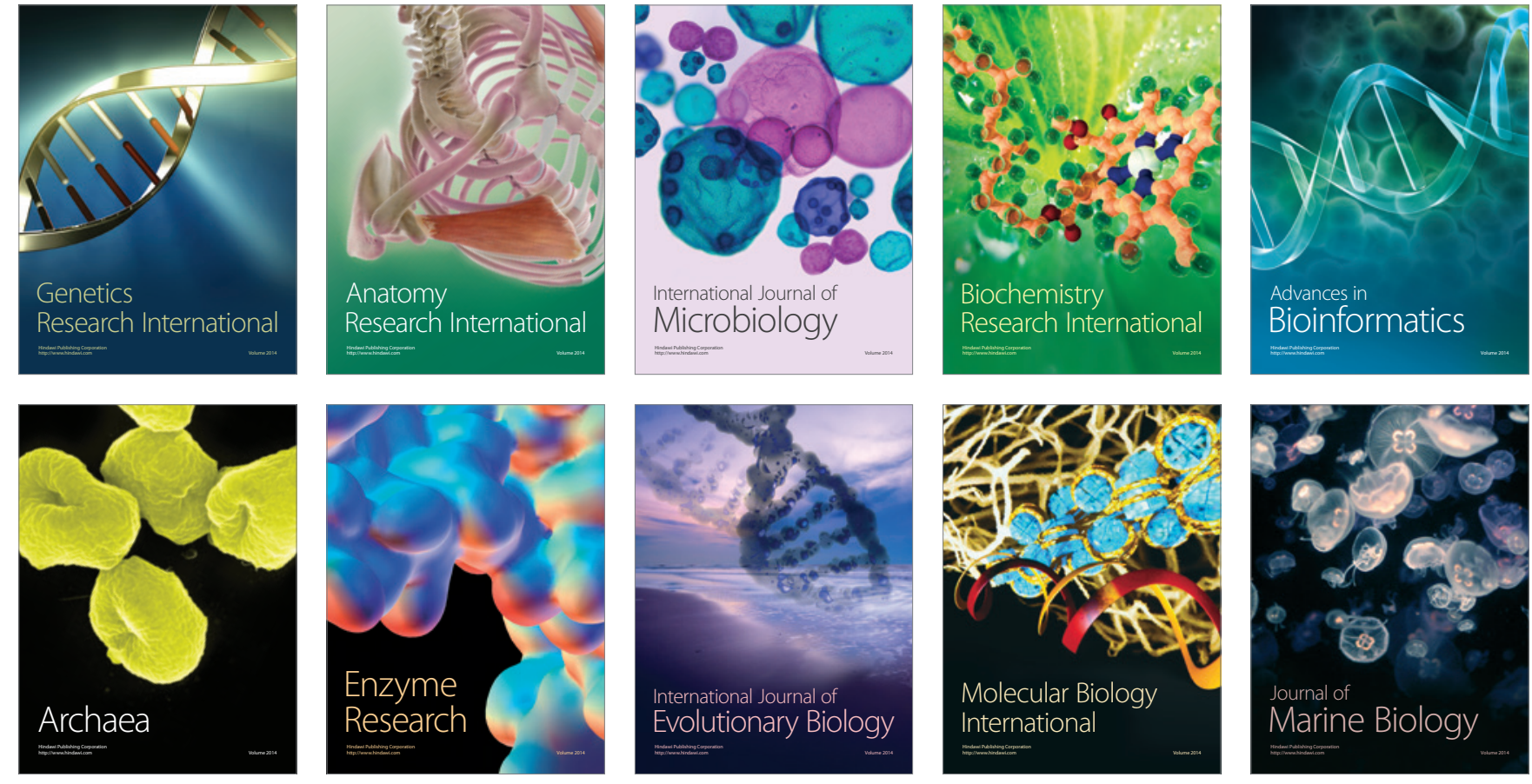